\title{
Continuous Culture Studies on the Biosynthesis of Alkaline Protease, Neutral Protease and $\alpha$-Amylase by Bacillus subtilis NRRL-B3411
}

\author{
By F. G. HEINEKEN* AND R. J. O'CONNOR† \\ New Enterprise Division, Monsanto Company, St Louis, Missouri, 63I66, U.S.A.
}

(Received 7 April 1972; revised I5 May I972)

S UMMARY

The amounts of three catabolite repressible enzymes, alkaline protease, neutral protease and $\alpha$-amylase, produced by Bacillus subtilis NRRL-B34I I growing in a chemostat, depended on the growth-limiting substrate. Limiting growth with glucose was advantageous for $\alpha$-amylase synthesis while nitrogen-limited growth was advantageous for synthesis of the two proteases. Under the conditions used, continuous cultures were unsuitable for large-scale production of the three enzymes since spontaneous mutations to less productive strains occurred in the long term.

\section{INTRODUCTION}

Continuous culture studies were initiated by us for two purposes. The first was to develop a better understanding of the regulatory mechanisms involved in the biosynthesis of alkaline protease, neutral protease and $\alpha$-amylase by Bacillus subtilis NRRL-B34II. Such information is fundamental to understanding how to alter these mechanisms in order to provide a desired type of micro-organism. The second was to investigate the possibility of synthesizing these enzymes in a large-scale continuous culture. Decided investment advantages (Ellsworth, Telling \& East, I959) of continuous cultures are discussed in the literature as well as some disadvantages (Butterworth, 1967).

A number of publications have appeared in recent years on the synthesis of exoenzymes, many of which are reviewed by Schaeffer (I969). Coleman (I967) reported that amylase and proteases of Bacillus subtilis are synthesized in the stationary phase of growth and appear simultaneously and in parallel fashion. Mandelstam (1967) postulates the concept of a catabolite repressing only the enzymes directly or indirectly producing it. We believe we have data which will help to clarify these concepts even further.

\section{METHODS}

Organism. The micro-organism used was Bacillus subtilis NRRL-B34I I.

Media. These consisted of a basic salt solution plus various carbohydrate and nitrogen sources. The basic salt solution contained (per 1 of distilled water): $\mathrm{FeSO}_{4} \cdot 7 \mathrm{H}_{2} \mathrm{O}, 0 \cdot 0 \mathrm{I} \mathrm{g}$; $\mathrm{ZnCl}_{2}, 0.02 \mathrm{~g} ; \mathrm{MnCl}_{2} .4 \mathrm{H}_{2} \mathrm{O}, 0.05 \mathrm{~g} ; \mathrm{MgSO}_{4}, 0.50 \mathrm{~g} ; \mathrm{CaCl}_{2} .2 \mathrm{H}_{2} \mathrm{O}, 0.50 \mathrm{~g} ; \mathrm{K}^{+}, 0.02 \mathrm{M} ; \mathrm{PO}_{4}{ }^{3-}$, $0.02 \mathrm{M}$; and EDTA, $0.00 \mathrm{I} \mathrm{M}$. This salts composition is a slightly modified version of that used by Schaeffer, Millet \& Aubert (1965) in their study on the sporulation of Bacillus megaterium.

* Present address: Webb-Waring Lung Institute, University of Colorado Medical Center, Denver, Colorado.

+ Present address: Department of Pediatrics, Washington University School of Medicine, St Louis, Missouri. 
These modifications resulted from calculations made from the salt composition data for $B$. subtilis given by Murrell ( 1967 ). Calcium was added to stabilize the enzymes (Keay \& Wildi, 1970; Keay, Moser \& Wildi, 1970; Moseley \& Keay, 1970). EDTA was added to prevent salt precipitation at the fermentation $\mathrm{pH}$.

All salts were reagent-grade chemicals. Acid-hydrolysed casein and monosodium glutamate were obtained from Sigma Chemical Company, St Louis, Missouri, U.S.A. Vitaminfree casein was obtained from Fisher Scientific Co. (C-203), St Louis, Missouri, U.S.A.

Media for the chemostat were sterilized by filtration through a $0.22 \mu \mathrm{m}$ Millipore filter. For the experiments with casein, a $10 \%(\mathrm{w} / \mathrm{v})$ solution was prepared and neutralized to $\mathrm{pH} 7.0$ with Io $\mathrm{M}-\mathrm{KOH}$ before being autoclaved for $30 \mathrm{~min}$ at $\mathrm{I} 2 \mathrm{I}{ }^{\circ} \mathrm{C}$. This solution was then diluted to $2 \%$ with filter-sterilized salts solution. All chemostat media were stored in 101 aspirator bottles. Shake-flask and Petri-dish media were steam-sterilized at $\mathrm{I}_{2 \mathrm{I}}{ }^{\circ} \mathrm{C}$ for 15 min.

Fermentation equipment and conditions. Flasks $(500 \mathrm{ml})$ containing $100 \mathrm{ml}$ of medium were inoculated from lyophilized spore cultures of Bacillus subtilis NRRL-B34II and shaken at $37^{\circ} \mathrm{C}$. Yeast extract $(0 \cdot 2 \%)$ was added to diluted (5:I) chemostat medium to aid spore germination. After full growth was obtained, the shake-flask cultures were added to the chemostat culture vessel ( $10 \%$ was a typical inoculum).

Shake-flask fermentations were carried out in a New Brunswick Incubator Shaker Model $\mathrm{G} 25$ at $37^{\circ} \mathrm{C}$ with a gyration speed of $250 \mathrm{rev}$. $/ \mathrm{min}$ and eccentricity I in.

Chemostat fermentations were carried out in a Model MA02 F I 21 continuous culture vessel from Fermentation Design, Allentown, Pennsylvania., U.S.A. The $\mathrm{pH}$ value was measured and controlled at $6 \cdot 3 \pm 0.1$ by a Fermentation Design $\mathrm{pH}$ control unit with an autoclavable Ingold $\mathrm{pH}$ electrode; $10 \mathrm{M}-\mathrm{H}_{3} \mathrm{PO}_{4}$ and $\mathrm{IO} \mathrm{M}-\mathrm{KOH}$ were used for $\mathrm{pH}$ control. Temperature was controlled at $37 \pm 0.5^{\circ} \mathrm{C}$. The culture volume varied from $\mathrm{I} \cdot 0$ to $\mathrm{I} \cdot 2 \mathrm{l}$, depending on the experiment. Foam was controlled using Mazer DF-2I C antifoam.

Turbidity. Turbidity measurements were made at $660 \mathrm{~nm}$ using a Beckman DU-2B spectrophotometer. Samples were diluted to give extinction readings in the range from 0.05 to 0.5 in a $\mathrm{I} \mathrm{cm}$ quartz cell.

Bacterial dry weight. Measurements were made in quadruplicate and averaged. Samples were centrifuged for $10 \mathrm{~min}$ at $20000 \mathrm{~g}$, the supernatant fluid decanted and the pellets placed in preweighed pans. The pellets were dried at $105^{\circ} \mathrm{C}$ for $24 \mathrm{~h}$ to constant weight. The relationship between turbidity and bacterial dry weight was linear. An extinction of Io corresponded to a bacterial dry weight of $4 \mathrm{mg} / \mathrm{ml}$.

Growth-rate measurements. These were made during batch growth from semilog plots of turbidity versus time. Growth rates under continuous culture conditions were set by the dilution rate of the culture.

Enzyme assays. Whole culture samples for enzymatic assays were frozen in dry ice immediately after sampling and stored at $-20^{\circ} \mathrm{C}$. Just before assay, samples were thawed, diluted and stored in an ice bath. Dilutions were carried out with $0.01 \%$ calcium acetate.

Neutral and alkaline protease activities were determined as caseinase activities at $\mathrm{pH}$ values of 7.0 and $10 \circ 0$, respectively. Keay (I97I) shows $\mathrm{pH}$ profile data which allow the activities of the two enzymes to be distinguished.

Most of the caseinase activity measurements were carried out on a Technicon autoanalyser with reagents as specified for the standard assay (Keay \& Wildi, 1970). Extinction was measured at $660 \mathrm{~nm}$ after treatment with Folin phenol reagent. Solutions of known protease activity were used to calibrate the autoanalyser at $\mathrm{pH}$ of 7 and 10 . Blanks were run with each assay by use of dual channels. 
$\alpha$-Amylase assays also were carried out on an autoanalyser. Colour reduction of potassium ferricyanide was measured and compared to values obtained from $\alpha$-amylase standards. Units were based on the dinitrosalicyclic acid assay method (Moseley \& Keay, 1970). Again, blanks were run with each assay.

Glucose assays. A glucose Tes-Tape ${ }^{\mathrm{R}}$ supplied by Eli Lilly, Indianapolis, Indiana, U.S.A., was used which gave qualitative results specific for glucose. More quantitative results were obtained when desired by use of Glucostat Special ${ }^{\mathrm{R}}$ supplied by Worthington Biochemical Corporation, Freehold, New Jersey, U.S.A.

Ammonia assays. The urea-nitrogen assay was used (Chaney \& Marbach, 1962) with reagents from the Hyland Division of Travenol Laboratories, Los Angeles, California, U.S.A. The Hyland procedure was utilized.

Glutamate assays. Deproteinized supernatants of samples were assayed with the ninhydrin method (Greenstein \& Winitz, I96I). Deproteinization was carried out by adding $4 \mathrm{ml}$ of $0.4 \mathrm{M}$-trichloroacetic acid to each $\mathrm{I} \mathrm{ml}$ of sample and centrifuging at $20000 \mathrm{~g}$ for $\mathrm{I}$ o min to remove suspended solids. The results were corrected by subtracting $\mathrm{NH}_{3}$ values obtained with the urea-nitrogen assay.

Colony characterizations. Standard microbiological tests (Breed, Murray \& Smith, I957; Conn, Jennison \& Weeks, 1957) were run on the variants obtained from the chemostat in the long-term experiments. Also, two phages specific for Bacillus subtilis NRRL-B34I I were used to check the variants. The standard phage overlay assay technique was used with Fisher J-I096-G phage assay base agar, Fisher J-I097-G phage assay overlay agar and Difco nutrient broth supplemented with I \% dextrose.

Theoretical equations used to study mutation phenomena. In an attempt to understand the spontaneous mutation phenomena found in this study, a kinetic model was derived based on that of Moser (1958), although his presentation is simplified. It is assumed that the chemostat culture is in a steady-state and contains $100 \%$ parent cells at zero time. Then consider that a small fraction of cells, $\lambda$, mutate during each generation. Kubitschek (1970) has recently shown that spontaneous mutations are a function only of the rate of DNA synthesis. Revertant frequencies are not important here as will be shown later. Then,

$$
\begin{aligned}
\frac{\mathrm{d} S}{\mathrm{~d} t} & =-\frac{\mathrm{I}}{Y_{1}} \frac{\mu_{1} S}{K_{m_{1}}+S} n_{1}-\frac{\mathrm{I}}{Y_{2}} \frac{\mu_{2} S}{K_{m_{2}}+S} n_{2}+D\left(S_{0}-S\right) \\
\frac{\mathrm{d} n_{1}}{\mathrm{~d} t} & =\frac{\mu_{1} S}{K_{m_{1}}+S}\left(n_{1}-\lambda n_{1}\right)-D n_{1}, \\
\frac{\mathrm{d} n_{2}}{\mathrm{~d} t} & =\frac{\mu_{2} S}{K_{m_{2}}+S} n_{2}+\frac{\mu_{1} S}{K_{m_{1}}+S} \lambda n_{1}-D n_{2} .
\end{aligned}
$$

where at

$$
t=0, \quad S=\frac{D}{\mu_{1}-D} K_{m_{1}}, \quad n_{1}=Y_{1}\left(S_{0}-S\right), \quad n_{2}=\text { o. }
$$

$D$ is the dilution rate $\left(\mathrm{h}^{-1}\right) ; K_{m}$, substrate saturation constant $(\mathrm{mg} / \mathrm{ml}) ; n$, bacterial dry weight $(\mathrm{mg} / \mathrm{ml}) ; S$, substrate concentration $(\mathrm{mg} / \mathrm{ml}) ; t$, time $(\mathrm{h}) ; Y$, yield coefficient $(\mathrm{g} / \mathrm{g})$; $\lambda$, mutation rate (mutation frequency per generation); $\mu$, maximal growth rate $\left(\mathrm{h}^{-1}\right)$; I refers to parent micro-organism and 2 refers to mutant micro-organism. The Monod model for growth is assumed to apply. 


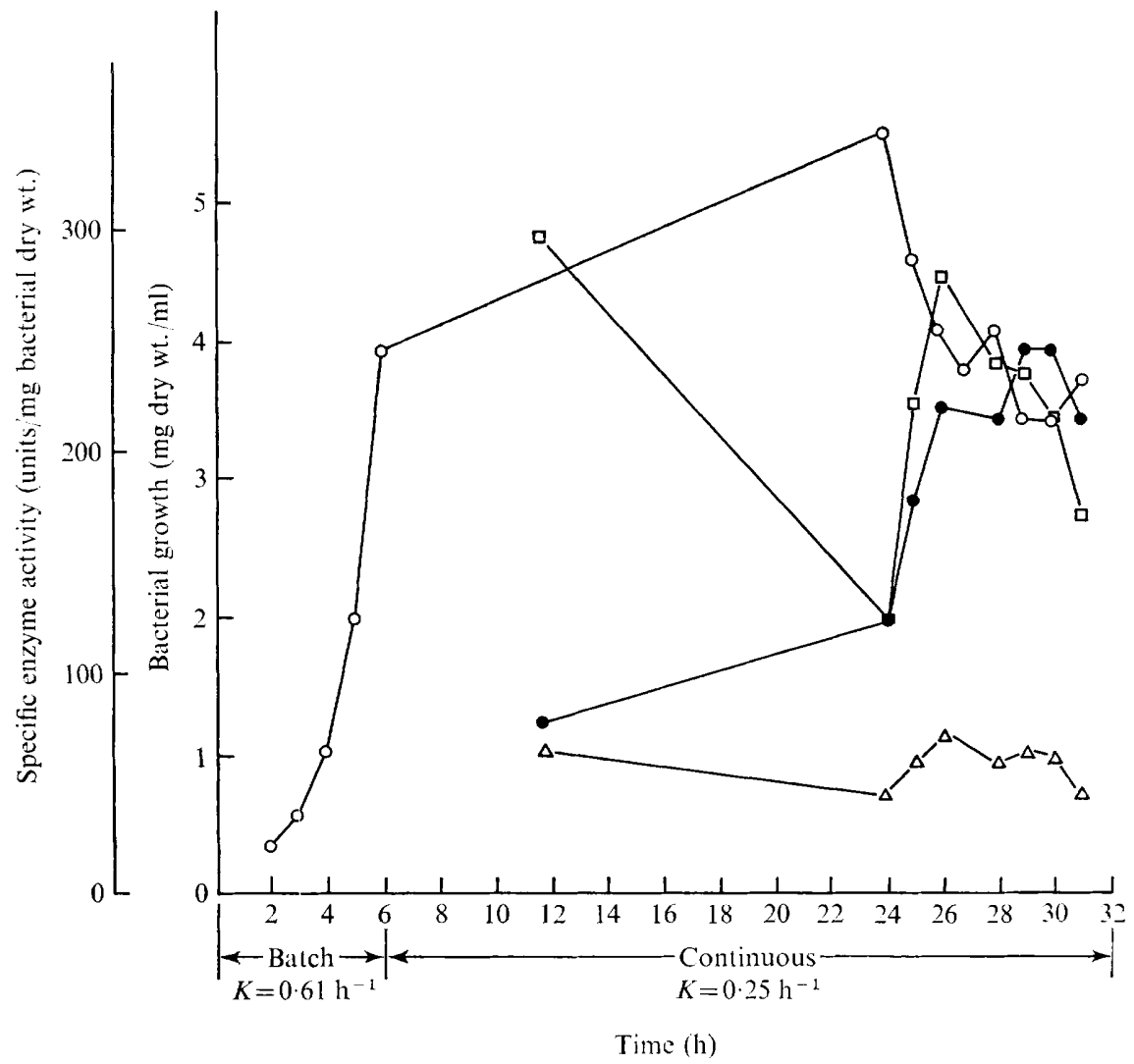

Fig. I. Enzyme synthesis by Bacillus subtilis on glucose $(1 \%)$ and $\mathrm{NH}_{4} \mathrm{Cl}(2 \%)$ with glucoselimiting growth. Runs I and $5 . \bigcirc$, Growth; $\Delta$, alkaline protease; $\square$, neutral protease; $\bigcirc, \alpha$ amylase.

\section{RESULTS}

When Bacillus subtilis NRRL-B34I I was grown on glucose ( $1 \%$ ) and $\mathrm{NH}_{4} \mathrm{Cl}(2 \%)$ with the standard salts solution, all three enzymes of interest were repressed during batch growth (Fig. I). Under chemostatic control with glucose as the limiting nutrient, however, all three enzymes appeared when the growth rate was decreased to $0.25 \mathrm{~h}^{-1}$.

In batch cultures with glucose (I \%) and acid hydrolysed casein $(0.5 \%)$, all three enzymes were repressed. Under chemostatic control at a growth rate of $0.3 \mathrm{~h}^{-1}$, the two proteases appeared in good quantity whereas no detectable $\alpha$-amylase was found (Fig. 2). Here, acidhydrolysed casein was found to be growth-limiting.

During growth on monosodium glutamate $(2 \%)$ in batch cultures all three enzymes appeared during log growth. Under chemostatic control the enzyme levels were the same as in batch growth with glutamate serving as both a carbon and nitrogen source (Fig. 3). Carbon was limiting since ammonia was found in the culture during the first $86 \mathrm{~h}$. At $86 \mathrm{~h}$ a switch to media containing glucose ( $1 \%$ ) and glutamate $(2 \%)$ was made. This caused a dramatic drop in all three enzyme levels at an equivalent growth rate. The two proteases reached non-detectable levels and the $\alpha$-amylase was decreased considerably. Assays showed glucose to be limiting in the latter part of the run. The drop in enzyme levels was not a result of a change in population (Fig. 5). 


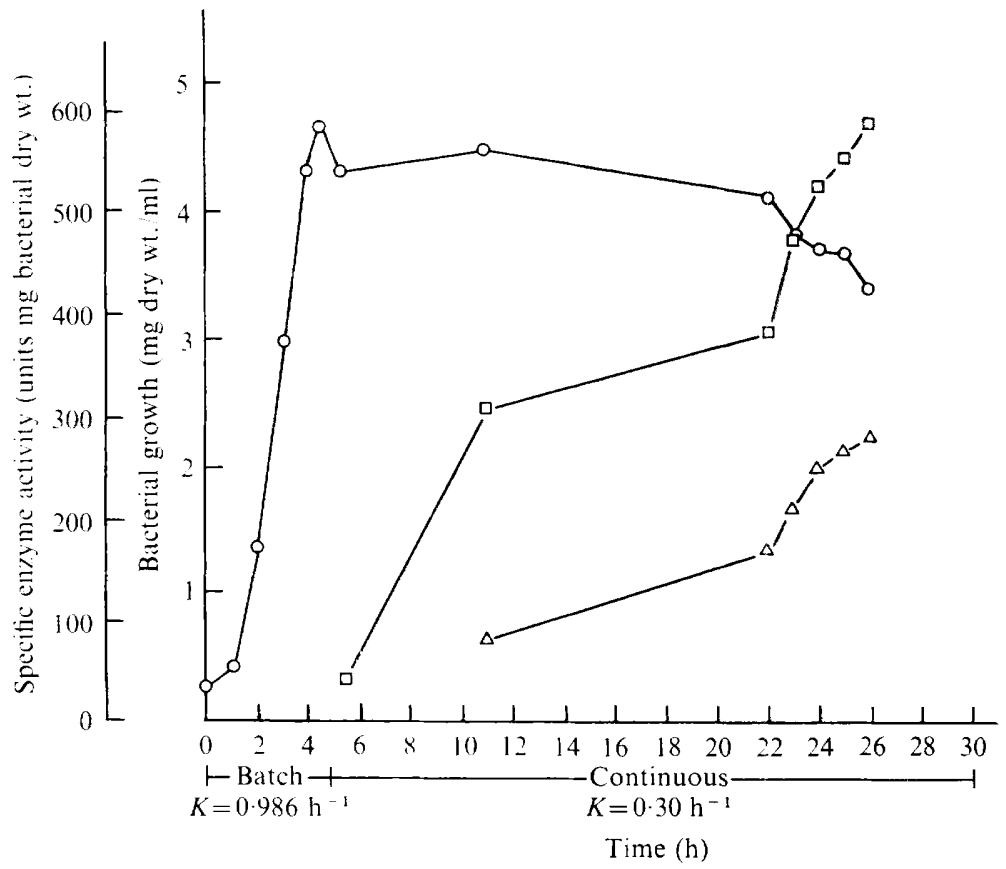

Fig. 2. Enzyme synthesis by Bacillus subtilis on glucose ( $1 \%$ ) and Casamino acids $(0.5 \%$ ) with nitrogen limiting growth. Runs 2 and 6.0 , Growth; $\Delta$, alkaline protease; $\square$, neutral protease.

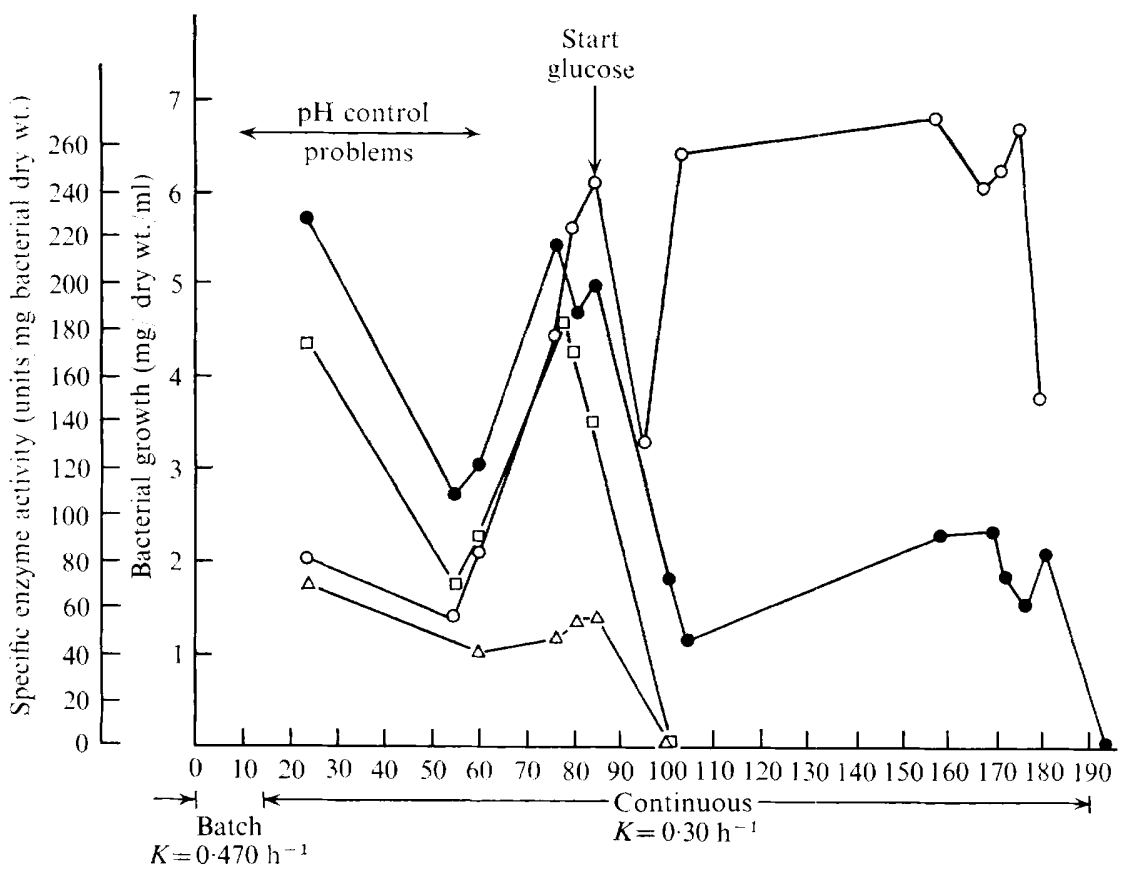

Time (h)

Fig. 3. Enzyme synthesis by Bacillus subtilis growing continuously on monosodium glutamate $(2 \%)$ and glucose $(\mathrm{I} \%)($ after $86 \mathrm{~h})$. Runs 7 and $7 a$. $\bigcirc$, Growth; $\triangle$, alkaline protease;, neutral protease; $\propto, \alpha$-amylase. 


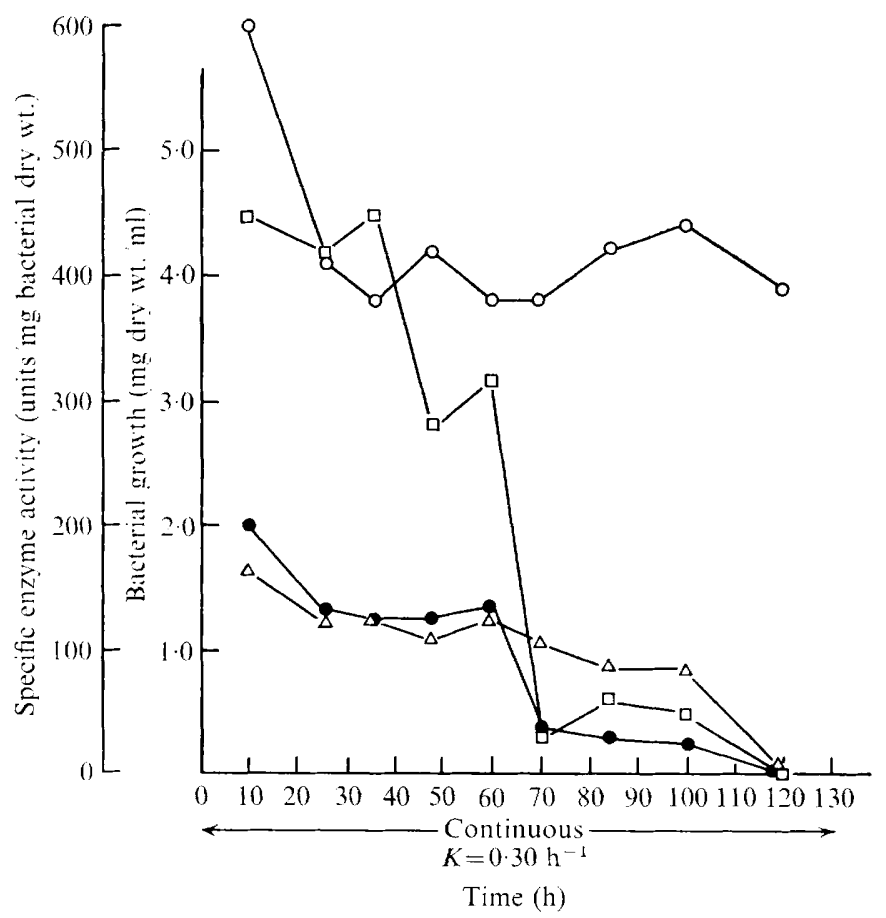

Fig. 4. Enzyme synthesis by Bacillus subtilis growing continuously on vitamin-free casein ( $2 \%$ ). Run 8. $\bigcirc$, Growth; $\triangle$, alkaline protease; $\square$, neutral protease; $\bullet, \alpha$-amylase.

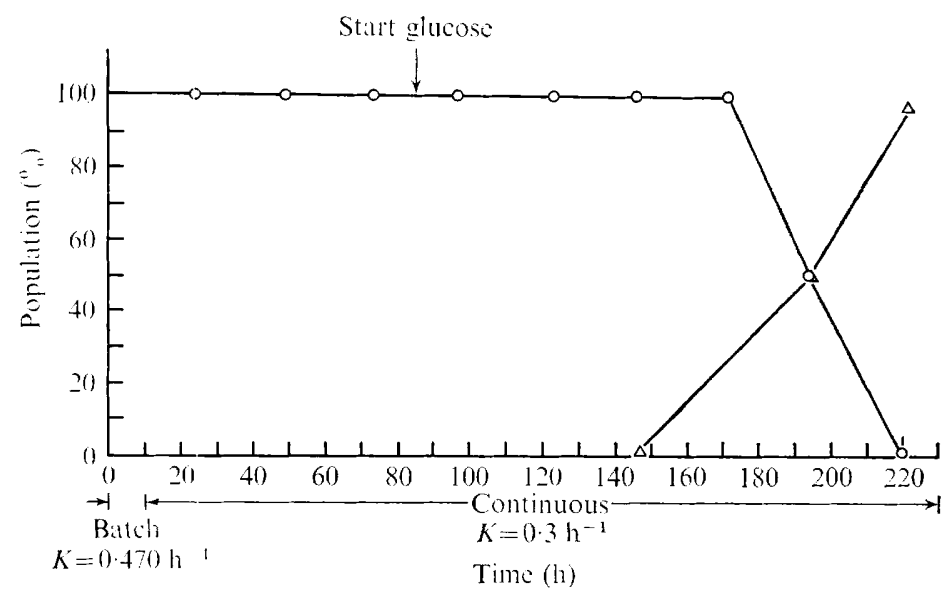

Fig. 5. Typical colony shift of Bacillus subtilis growing on monosodium glutamate (2\%) and glucose $(\mathrm{I} \%$ ). $\bigcirc$, Parent or wild-type micro-organism; $\triangle$, mutant micro-organism.

During growth on vitamin-free casein $(2 \%)$ in batch cultures, the three enzymes were again derepressed during the entire growth curve. In a chemostat with a growth rate of $0.30 \mathrm{~h}^{-1}$, a precipitous drop in enzyme levels occurred at $60 \mathrm{~h}$ due to a less productive Bacillus subtilis NRRL-B34II variant taking over the culture (Fig. 4). A takeover of continuous cultures by mutants occurred in other media; for example, after growth of the parent strain on glucose (I \%) and glutamate $(2 \%, w / v)$ for about I6o h (Fig. 5).

Theoretical calculations of colony shifts were made with assumed values for some of the 


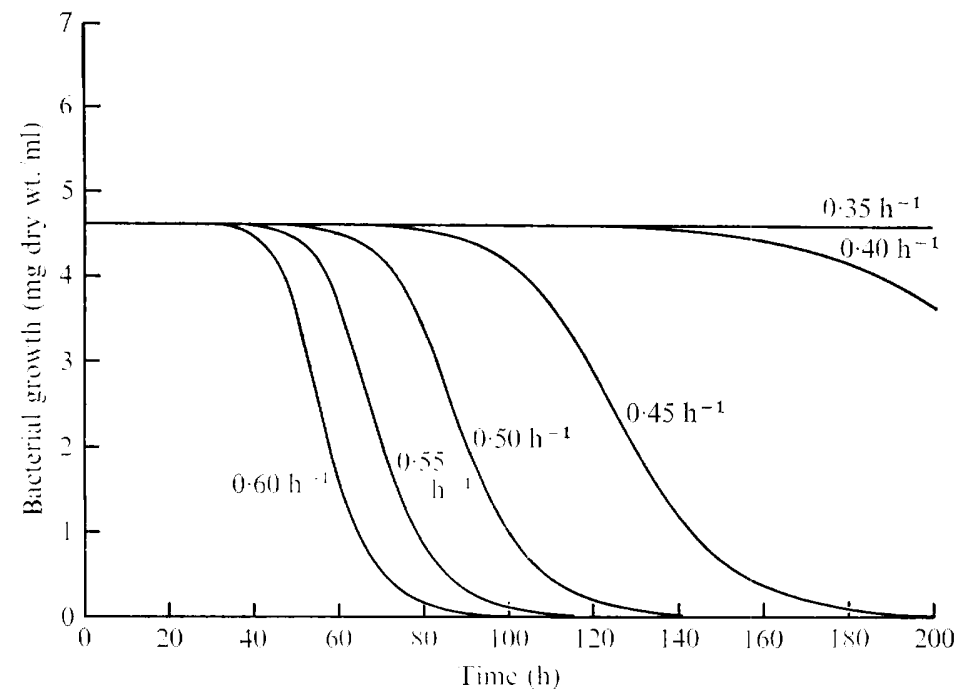

Fig. 6. Theoretical calculations $\left(n_{1}\right)$ for colony shifts of Bacillus subtilis at various values of $\mu_{2}$, the maximal growth rate of the mutant micro-organism.

parameters (Fig. 6). Values derived from our experiments were: $Y_{1}$ and $Y_{2}, 0 \cdot 33 ; S_{0}$, initial substrate concentration, $20 \mathrm{mg} / \mathrm{ml} ; D, 0.30 \mathrm{~h}^{-1} ; K_{m_{1}}, \mathrm{I} \cdot 0 \mathrm{mg} / \mathrm{ml} ; \mu_{1}, 0.35 \mathrm{~h}^{-1} ; K_{m_{2}}$ was assumed equal to $K_{m_{1}}$. The calculations were not very sensitive to changes in $K_{m_{2}}$. Almost equivalent results were obtained with values for this parameter of 2.0 or 0.5 . A relatively high value of $10^{-5}$ was chosen for $\lambda$ but values of $10^{-4}$ or $10^{-6}$ had little effect on the response curves (Fig. 6). These calculations were not affected by assuming similar values for a revertant mutation frequency. The parameter of greatest sensitivity was $\mu_{2}$, the maximal growth rate of the mutant micro-organism. Differences of $0 \cdot \mathrm{I}$ to $0.25 \mathrm{~h}^{-1}$ in the growth rates between host and mutant micro-organism showed response curves very similar to our data. Such differences are not uncommon (Moser, 1958).

\section{DISCUSSION}

The experiments conducted in this study (Table I) show that the regulation of $\alpha$-amylase synthesis is different from that of the proteases. The $\alpha$-amylase is severely repressed whenever glucose is in excess (runs I, 2 and 6). Glucose repression of amylase synthesis was first demonstrated by Katz (1898).

Although amylase regulation differs from the regulation of the two proteases, the proteinases appear to be regulated co-ordinately and therefore possibly by the same effector molecule. When one protease was completely repressed so was the other (runs 1, 2 and $7 a$ ). When both were produced the ratio of the specific activities of the neutral to alkaline proteases ranged from $2 \cdot 2$ to $3 \cdot 6$.

Runs I, 2 and 7 confirm previous observations made on protease syntheses by Bacillus licheniformis (Laishley \& Bernlohr, I966, I 968). Bacillus subtilis NRRL-B34I I growing at a rate of $0.6 \mathrm{I} \mathrm{h}^{-1}$ on glucose- $\mathrm{NH}_{4}$ salts repress protease synthesis completely. This repression is catabolic since it is relieved by growth on glutamate. The slower growth rate on glutamate $\left(0.47 \mathrm{~h}^{-1}\right)$ may contribute to the derepression (Fabian, I969). However, a more important factor is the nature of the limiting nutrient, as shown in run 7 where a switch to a glucoselimited medium completely repressed the proteases. 
Table I. Specific enzyme activities from batch and continuous cultures of Bacillus subtilis

\begin{tabular}{|c|c|c|c|c|c|c|c|c|c|}
\hline Run & Mode & $\begin{array}{l}\text { Growth } \\
\text { rate } \\
\left(\mathrm{h}^{-1}\right)\end{array}$ & cultures of & $\begin{array}{l}\text { Limiting } \\
C \text { or } N\end{array}$ & $\begin{array}{l}\text { Nature } \\
\text { of } \\
\text { limiting } \\
\text { compound }\end{array}$ & $\begin{array}{c}\begin{array}{c}\text { Specifi } \\
\text { enzym }\end{array} \\
\alpha- \\
\text { Amylase }\end{array}$ & $\begin{array}{l}\text { activi } \\
\text { (uni }\end{array}$ & $\begin{array}{l}\text { of } \\
n g \text { ) }\end{array}$ & $\begin{array}{c}\text { Ratio } \\
\text { NP/ } \\
\text { AP }\end{array}$ \\
\hline $\begin{array}{l}\text { I } \\
2 \\
3 \\
4\end{array}$ & Batch & $\left\{\begin{array}{l}0.6 \mathrm{I} \\
0.99 \\
0.47 \\
0.33\end{array}\right.$ & $\left.\begin{array}{l}\text { Glucose- } \mathrm{NH}_{4} \\
\text { Glucose-Cas AAs } \\
\text { Glutamate }(2 \%) \\
\text { Casein }(2 \%)\end{array}\right\}$ & Neither & None & $\left\{\begin{array}{r}0 \\
0 \\
200 \\
175\end{array}\right.$ & $\begin{array}{r}0 \\
0 \\
140 \\
450\end{array}$ & $\begin{array}{r}0 \\
0 \\
65 \\
165\end{array}$ & $\begin{array}{l}- \\
2 \cdot 2 \\
2 \cdot 7\end{array}$ \\
\hline $\left.\begin{array}{l}5 \\
6\end{array}\right)$ & & $\left(\begin{array}{l}0.25 \\
0.3\end{array}\right.$ & $\begin{array}{l}\text { Glucose- } \mathrm{NH}_{4} \\
\text { Glucose-Casamino } \\
\text { acids }\end{array}$ & $\begin{array}{l}\mathrm{C} \\
\mathrm{N}\end{array}$ & $\begin{array}{l}\text { Glucose } \\
\text { Cas-AAs }\end{array}$ & $\begin{array}{r}225 \\
0\end{array}$ & $\begin{array}{l}225 \\
475\end{array}$ & $\begin{array}{r}70 \\
225\end{array}$ & $\begin{array}{l}3 \cdot 2 \\
2 \cdot I\end{array}$ \\
\hline $\begin{array}{l}7 \\
7 a\end{array}$ & Continuous & $\begin{array}{l}0.3 \\
0.3\end{array}$ & $\begin{array}{l}\text { Glutamate }(2 \%) \\
\text { Glutamate }(2 \%) \\
\text { and glucose }(1 \%)\end{array}$ & $\begin{array}{l}\text { C } \\
\text { C }\end{array}$ & $\begin{array}{l}\text { Glutamate } \\
\text { Glucose }\end{array}$ & $\begin{array}{r}200 \\
25\end{array}$ & $\begin{array}{r}180 \\
0\end{array}$ & $\begin{array}{r}50 \\
0\end{array}$ & $\begin{array}{l}3 \cdot 6 \\
0\end{array}$ \\
\hline 81 & & 10.3 & Casein $(2 \%)$ & $\mathrm{C}$ & 一 & I 25 & 375 & I 25 & $3 \cdot 0$ \\
\hline
\end{tabular}

Bacillus protease synthesis is repressed catabolically and by amino acids (Chaloupka, 1969); although both glucose and amino acids each repress megateriopeptidase synthesis, both are required for complete repression and at low amino acid concentrations, glucose has little or no protease-repressing activity. We confirmed his findings (run 6). The best differential rate of synthesis of the two proteases occurred in the presence of glucose-Casamino acids during nitrogen-limited growth.

The dual requirement for a glucose catabolite and a nitrogen source for repression of protease synthesis is identical to the requirements for the repression of Bacillus subtilis tricarboxylic acid (TCA) enzymes (Hanson, Blicharska, Arnaud \& Szulmajster, 1964). Since the proteases and a functional TCA cycle appear at about the same time during growth and sporulation of $B$. subtilis, all of these enzymes may well be under the control of the same effector molecule. Hanson et al. (I964) suggested that this molecule might be 'glutamate or a derivative of glutamate'. The following model suggests that glutamine plays a key role in regulating these enzymes.

While Bacillus subtilis NRRL-B34I I is growing on glucose-Casamino acids, it is carrying out the following reactions:

$$
\text { glutamate }+\mathrm{NH}_{4}{ }^{+}+\mathrm{ATP} \longrightarrow \text { glutamine. }
$$

Since this is a highly endothermic reaction, a molecule of ATP is expended for each molecule of glutamine synthesized. The glutamine, in turn, participates in the formation of aminosugars (wall and membrane precursors; Bates \& Pasternak, I965).
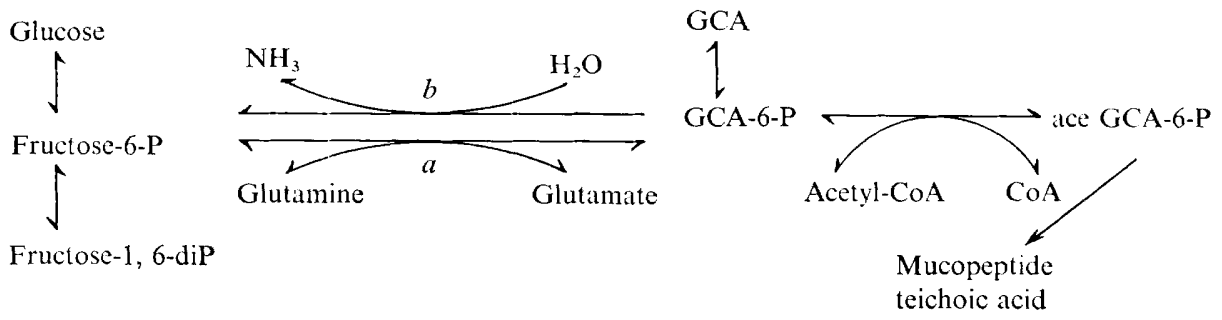

$a$, Fructose-6-P-aminotransterase; $b$, glucosamine-6-P-deaminase (Freese, Cole, Klofat \& Freese, I970); GCA, D-glucosamine; GCA-6-P, D-glucosamine-6-P; ace GCA-6-P, $N$-acetyl-D-glucosamine6-P 
$N$-acetyl-D-glucosamine-6-phosphate produces a severe 'permanent catabolite repression' of $\beta$-galactosidase synthesis, which, in turn, is reversible by cyclic $3^{\prime}, 5^{\prime}$-adenosine monophosphate (C-AMP) (Goldenbaum, Broman \& Dobrogosz, 1970). Our data are consistent with the idea that $N$-acetyl-D-glucosamine-6-phosphate is involved in the repression of the proteases and TCA cycle enzymes. Metabolic conditions favouring its synthesis (the availability of fructose-6-phosphate and glutamine) favour continued growth. Metabolic conditions favouring its degradation (relief of repression of the GCA-6-deaminase by exhaustion of glucose) (depletion of fructose-6-P or glutamine) favour derepression of the proteases, and TCA cycle enzymes; and the initiation of sporulation.

The large scale production of the three enzymes could not be achieved in continuous cultures under the conditions we used. The use of chemostats for this purpose depends on devising conditions under which the selective pressures inherent in a chemostat favour the continued existence of the enzyme producing micro-organism. The potential methods for doing this (e.g. feeding a peptide antibiotic which the wild-type digests but to which the protease deficient mutants are sensitive) are all thwarted by the extracellular nature of the enzymes. Conditions favouring the growth of the wild-type are equally favourable to the enzyme-less mutant, since the product of the enzyme is available to both. Perhaps by employing mutants unable to secrete the various enzymes, one might select hyperproductive strains from heterogeneous populations.

We appreciate the excellent technical assistance of R. Eaton, Y. W. Hawthorne and P. L. McGowen in making this study possible. We are especially thankful to Dr P. H. Hodson for helping to set up the autoanalyser enzyme assays and to R. Kralovic for supplying the two phages used to characterize the Bacillus subtilis variants.

\section{REFERENCES}

Bates, C. J. \& Pasternak, C. A. (1965). Further studies on the regulation of amino sugar metabolism in Bacillus subtilis. Biochemical Journal 96, 147-154.

Breed, R. S., Murray, E. G. D. \& Smith, N. R. (1957). Bergey's Manual of Determinative Bacteriology, 7 th edn. Baltimore: Williams and Wilkins.

BUtTERWORTH, D. (1967). Factors determining the choice of batch or continuous fermentation. In Biology and the Manufacturing Industries. Edited by M. Brooks. New York: Academic Press.

Chaloupka, J. ( I969). Dual control of megateriopeptidase synthesis. Annales Institute Pasteur II 7, 63 I-636.

Chaney, A. L. \& Marbach, E. P. (1962). Modified reagents for determination of urea and ammonia. Clinical Chemistry 8, I $30-132$.

Coleman, G. (I967). Studies on the regulation of extracellular enzyme formation by Bacillus subtilis. Journal of General Microbiology 49, 42 I-43I.

Conn, H. J., Jennison, M. W. \& WeEks, O. B. (1957). Routine tests for the identification of bacteria. In Manual of Microbiological Methods, pp. 140-168. New York: McGraw-Hill.

Ellsworth, R., Telling, R. C. \& East, D. N. ( 1959). The investment value of continuous culture. Journal of Applied Bacteriology 22, $138-152$.

Fabian, J. (1969). Protease synthesis of Bacillus pumilus grown in continuous culture. In Continuous Cultivation of Microorganisms. Edited by I. Malek, K. Beran, Z. Fencl, V. Munk, J. Ricica \& H. Smrckova. New York: Academic Press.

Freese, E. B., Cole, R. M., Klofat, W. \& Freese, E. (I970). Growth sporulation and enzyme defects of glucosamine mutants of Bacillus subtilis. Journal of Bacteriology ror, 1046-1062.

Goldenbaum, P. E., Broman, R. L. \& Dobrogosz, W. J. (1970). Cyclic 3',5'-adenosine monophosphate and $\mathrm{N}$-acetylglucosamine-6-phosphate as regulatory signals in catabolic repression in the lac operon in Escherichia coli. Journal of Bacteriology 103, 663-670.

Greenstein, J. P. \& Winitz, M. (I96I). Chemistry of the Amino Acids, vol. 2, pp. I299-1317. New York: Wiley. 
Hanson, R. S., Blicharska, J., Arnaud, M. \& Szulmajster, J. (I964). Observations on the regulation of the synthesis of the tricarboxylic acid cycle enzymes in Bacillus subtilis Marburg. Biochemical and Biophysical Research Communications $\mathbf{1 7}, 690-695$.

KATZ, J. (I898). Jahrbuch für wissenschaftliche Botanik 3r, 599. Cited by K. Daigen \& B. Williams (I970). Catabolite repression and other control mechanisms in carbohydrate utilization. Advances in Microbial Physiology 4, 25I-324.

KeAY, L. (197I). Microbial proteases. Process Biochemistry 68, 17-21.

Keay, L., Moser, P. W. \& Wildi, B.S. (1970). Proteases of the genus Bacillus. II. Alkaline proteases. Biotechnology and Bioengineering 12, $213-249$.

KeAY, L. \& WILDI, B. S. (1970). Proteases of the genus Bacillus. I. Neutral proteases. Biotechnology and Bioengineering 12, 179-212.

KubitscheK, H. E. (1970). Nuclear selection in filamentous bacteria: Resolution of the Novick-Szilard Paradox. Ioth International Congress of Microbiology, 1970, Colloquium Ci 1-3.

LAISHLEY, E. J. \& BeRnLOHR, R. W. (I966). Catabolic repression of several sporulation enzymes during growth of Bacillus licheniformis Bacteriological Proceedings, 97.

LAISHLeY, E. J. \& BeRnlohr, R. W. (1968). Regulation of arginine and proline catabolism in Bacillus licheniformis. Journal of Bacteriology 96, 322-329.

MANDELSTAM, J. (1967). End product repression and the regulation of degradative enzymes. In Regulation of Nucleic Acid, and Protein Synthesis, pp. 36I-356. Edited by V. V. Koningsberger and L. Bosch. Amsterdam: Elsevier Publishing Co.

Moseley, M. H. \& KeaY, L. (1970). Purification and characterization of the amylase of Bacillus subtilis NRRL-B34I I. Biotechnology and Bioengineering r2, 25I-271.

Moser, H. (1958). The Dynamics of Bacterial Populations Maintained in the Chemostat. Publication G I4. Washington D.C : Carnegie Institution.

Murrell, W. G. (1967). The biochemistry of the bacterial endospore. Advances in Microbial Physiology r, I33-25I.

SCHAEFFER, P. (1969). Sporulation and the production of antibiotics, exoenzymes and exotoxins. Bacteriological Reviews 33, 48-7I.

Schaeffer, P., Millet, S. \& Aubert, J. P. (1965). Catabolite repression of bacterial sporulation. Proceedings of the National Academy of Sciences of the United States of America. 54, 704-7I I. 